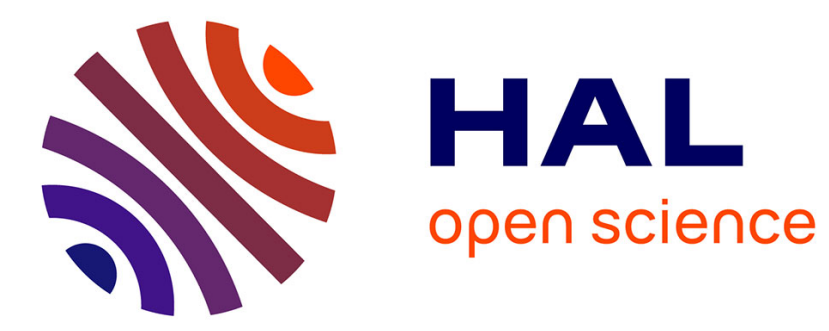

\title{
CMAS 3D, a new program to visualize and project major elements compositions in the CMAS system
} Lyderic France, N. Ouillon, G. Chazot, J. Kornprobst, Pierre Boivin

\section{To cite this version:}

Lyderic France, N. Ouillon, G. Chazot, J. Kornprobst, Pierre Boivin. CMAS 3D, a new program to visualize and project major elements compositions in the CMAS system. Computers \& Geosciences, 2009, 35 (6), pp.1304-1310. 10.1016/j.cageo.2008.07.002 . hal-00413570

\author{
HAL Id: hal-00413570 \\ https://hal.science/hal-00413570
}

Submitted on 7 Dec 2019

HAL is a multi-disciplinary open access archive for the deposit and dissemination of scientific research documents, whether they are published or not. The documents may come from teaching and research institutions in France or abroad, or from public or private research centers.
L'archive ouverte pluridisciplinaire HAL, est destinée au dépôt et à la diffusion de documents scientifiques de niveau recherche, publiés ou non, émanant des établissements d'enseignement et de recherche français ou étrangers, des laboratoires publics ou privés. 
1 CMAS 3D, a new program to visualize and project major elements compositions in the

2 CMAS system.

3 France L. ${ }^{*}$, Ouillon N., Chazot G. ${ }^{* *}$, Kornprobst J., Boivin P.

4

5 Laboratoire Magmas et Volcans, OPGC - UBP - CNRS, 5, rue Kessler, 63038 Clermont-

6 Ferrand Cedex, France

7

8 *: Present address : Géosciences Montpellier, Université Montpellier 2 - CNRS, 34095

9 Montpellier cedex 05, France

10 Corresponding author: France@gm.univ-montp2.fr

11 Equipe Manteau-Noyau

12 Laboratoire Géosciences Montpellier

13 CC 060 Université de Montpellier II

14 Place Eugène Bataillon

$15 \quad 34095$ Montpellier Cedex 5

16 FRANCE

17 Phone : +33467143944

18 Fax: +33467143603

19

$20 * *$ : Present address : UMR 6538 “Domaines Océaniques”, IUEM, Université de Bretagne

21 Occidentale, Place Copernic, 29280 Plouzané, France 
Abstract

CMAS 3D, developed in MATLAB ${ }^{\circledR}$, is a program to support visualization of major element chemical data in three dimensions. Such projections are used to discuss correlations, metamorphic reactions and the chemical evolution of rocks, melts or minerals. It can also project data into 2D plots. The CMAS 3D interface makes it easy to use, and does not require any knowledge of Matlab ${ }^{\circledR}$ programming. CMAS 3D uses data compiled in a Microsoft Excel $^{\mathrm{TM}}$ spreadsheet. Although useful for scientific research, the program is also a powerful tool for teaching.

\section{Key words: CMAS system, 3D, projection.}

\section{1-Introduction}

Major element chemical data of rocks and minerals are of great use in the study of the origins and evolution of magmatic and metamorphic rocks. Petrologists mostly use binary plots to evaluate correlation between chemical elements or oxides, but some reduced systems have been developed to take into account more than 2 elements in the same diagram. For example some software packages such as MinPet (Richard, 1997), IgPet (Carr, 1995), NewPet (Clarke, 1993), Petrograph (Petrelli, 2003) or GeoPlot (Zhou and Li, 2006) have been developed for better data visualization and interpretation. Smith and Beermann (2006) proposed to use multivector diagrams to represent up to nine components. O'Hara (1968) introduced the use of the $\mathrm{CaO}-\mathrm{MgO}-\mathrm{Al}_{2} \mathrm{O}_{3}-\mathrm{SiO}_{2}$ (CMAS) system allowing representation of 13 oxides in a four dimension representation. This pseudo-quaternary projection has been largely used as it is the simplest way to represent the major element composition of mafic and ultramafic rocks 
1 (Garrido and Bodinier, 1999), as well as the main crustal and mantle minerals (Kornprobst,

2 1970; Kornprobst and Conquéré, 1972) or extraterrestrial objects (Grossman and Fedkin,

3 2003; Grossman et al., 2002; Yoneda and Grossman, 1995) and serves as a good model for

4 dry basaltic melts (Schiano et al., 2000; Schiano et al., 2004). It is also largely used in

5 experimental petrology (Hirschmann et al., 2003; Kogiso et al., 2003; Kogiso et al., 2004).

6 Here we present CMAS 3D, a program written in MATLAB $6.5{ }^{\circledR}$. It converts oxide data to

7 CMAS coordinates and allows visualization of these data in 3 dimensions, and projects the data onto two dimensional plots. Using CMAS 3D does not require MATLAB programming

9 expertise. It reads data from a Microsoft Excel $^{\mathrm{TM}}$ spreadsheet. The visualization uses the VRML (Virtual Reality Modeling Language) allowing the rotation of the CMAS tetrahedron

11 in all directions in order to evaluate the different correlations and reactions. CMAS 3D also

permits the addition of lines or planes between the analyzed rocks or minerals for the purposes of testing for metamorphic reactions or exsolutions, or to illustrate specific chemical trends. The proportion of the mineral phases that are involved in a reaction as reagents or as products is represented by the balanced centroid on a line (for two reagents or products), on a plane (for three reagents or products) or in a polyhedron (for more than three reagents or products). The intersection between the geometric form formed by the reagents and the one formed by the products in CMAS space is a test of the chemical feasibility of the reaction.

\section{2-Program philosophy and projection system}

The CMAS system is a good analog for the main minerals contained in mafic and ultramafic rocks, mainly olivine, magnesian and aluminous pyroxenes (enstatite and polymorphs, pigeonite, diopside), and aluminous phases (plagioclases, spinels, grossular-pyrope solid solutions), as well as for mafic and ultramafic magmas. O’Hara (1968 and 1976) proposed the 
1 pseudo quaternary projection by defining the following CMAS components in terms of mole

2 fractions of the oxides:

$3 \mathrm{C}_{0}=100\left(\mathrm{CaO}-(3+1 / 3) \mathrm{P}_{2} \mathrm{O}_{5}+2 \mathrm{Na}_{2} \mathrm{O}+2 \mathrm{~K}_{2} \mathrm{O}\right) * 56.08$

$4 \quad \mathrm{M}_{0}=100\left(\mathrm{MgO}+\mathrm{FeO}+\mathrm{MnO}+\mathrm{NiO}-\mathrm{TiO}_{2}\right) * 40.32$

$5 \quad \mathrm{~A}_{0}=100\left(\mathrm{Al}_{2} \mathrm{O}_{3}+\mathrm{Fe}_{2} \mathrm{O}_{3}+\mathrm{Cr}_{2} \mathrm{O}_{3}+\mathrm{TiO}_{2}+\mathrm{Na}_{2} \mathrm{O}+\mathrm{K}_{2} \mathrm{O}\right) * 101.96$

$6 \quad \mathrm{~S}_{0}=100\left(\mathrm{SiO}_{2}-2 \mathrm{Na}_{2} \mathrm{O}-2 \mathrm{~K}_{2} \mathrm{O}\right) * 60.085$

7 and:

$8 \quad \mathrm{Sum}=\mathrm{C}_{0}+\mathrm{M}_{0}+\mathrm{A}_{0}+\mathrm{S}_{0}$

9 with:

$10 \mathrm{C}=\mathrm{C}_{0} / \mathrm{Sum}$

$11 \mathrm{M}=\mathrm{C}_{0} / \mathrm{Sum}$

$12 \quad \mathrm{~A}=\mathrm{C}_{0} / \mathrm{Sum}$

$13 \mathrm{~S}=\mathrm{C}_{0} / \mathrm{Sum}$

14 The $\mathrm{C}, \mathrm{M}, \mathrm{A}$ and $\mathrm{S}$ results are the respective coordinates of the apices in the CMAS

15 tetrahedron.

16 Four different types of representations are possible with CMAS 3D: $(i)$ the projection in

17 moles presented above from O'Hara (1968), (ii) the same projection but in weight percent,

18 (iii) a modified version proposed in the Basaltic Volcanism Study Project (1981) (hereafter

19 BVSP_81) in moles and (iv) the same modified version in weight percent.

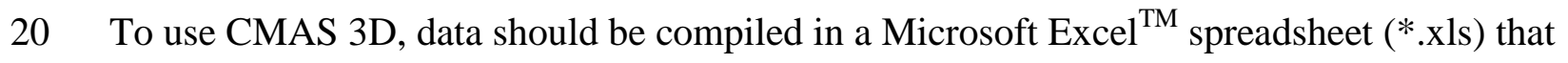

21 should have the format depicted in the table 1 (this file is called hereafter data.xls). A first

22 column contains the sample name (only one word), the 3 following ones contain the symbol

23 ( 1 for a sphere and 2 for a cube), the size ( 8 for a medium size) and the color (between 1 and

24 12, see the file "C:ICMAS_1.2lcolors\&symbols.jpg") selected for the representation. The next

25 columns contain the oxides organized in 13 columns in the same order as presented in the 
1 table 1. The last column contains the total. No cells should be empty, but zero could be

2 written.

\section{3-Starting the program}

On a PC the folder "CMAS_1.2" should be copied on the "C:l" directory, no installation is necessary. A version of Matlab 6.5 ${ }^{\circledR}$ or younger is required to use CMAS 3D. When MATLAB is open "C:ICMAS_1.2" should be writen in the "Current Directory" (No.1, Fig. 1) and then the program is loaded by writing "cmas" in the "Command Window" (No.2, Fig. 1). Once the interface of CMAS 3D is open (Fig. 2), it is ready to be used, as described in the next section.

\section{4-Functionalities}

\section{1-CMAS tetrahedron}

First of all empty CMAS tetrahedrons could be generated by selecting a file name and

17 pressing the associated button (No.1, Fig. 2), files are stored in the folder

“CMAS_1.2\Resultats”. Before loading the data file (data.xls), a projection system (O’Hara_moles; O’Hara_wt\%; BVSP_81_moles or BVSP_81_wt\%) must be chosen from the interface illustrated in Figure 2 (No.1). Then the option "Probe file loading" is selected (No.2,

21 Fig. 2). This opens a new window that allows the data file (e.g. data.xls) to be chosen; a final window is then opened and an output-file has to be chosen. When the data.xls type file is

23 loaded, the size of the file is written in the central frame (No.3, Fig. 2). Two different

24 numbers are present: the first one is the number of samples and the second one, the number of 
1 columns (it should be 17). The CMAS coordinates of the samples are written in the

2 “Command Window" (No.2, Fig. 1) in percent as:

3

4

5

6

These coordinates are also stored file.

\section{2-Adding Points or Minerals}

This option allows adding some common minerals or some points if their coordinates in the CMAS space are known. To use this option, the line "Add a point" should be selected (No.2, Fig. 2). To add a common mineral, select it in the drop-down menu (No.4, Fig. 2).

Once the mineral is selected, the output-file has to be selected. To add a point from its CMAS coordinates, these coordinates should be written in the four boxes (No.4, Fig. 2) and the sum should be 1. A name could be given in the upper case and a color should be chosen just below (No.5, Fig. 2); to export, the button "export" should be activated. As above, an output-file should be selected.

\section{3-Adding Lines and Planes}


1 rock compositions, or to track the evolution of melt during melting or crystallization. To add

2 lines and planes, the line "Draw lines \& planes" should be selected (No.2, Fig. 2). Then there

3 are three choices in the menu (No.6, Fig. 2): (i) add the particular plane corindon-enstatite-

4 wollastonite (co-en-wo or A-MS/2-CS-2), (ii) add another plane and (iii) add a line. For (ii)

5 and (iii) there are two possibilities to select the apices: $(a)$ use some samples that are in the

6 data.xls type file or $(b)$ use common minerals. For $(a)$, the number of the line (in the data.xls

7 file, Table 1) of the used sample should be written in the three (for a plane) or two (for a line)

8 boxes. For $(b)$, the abbreviation of the minerals should be used (Table 2). Note that both $(a)$

9 and $(b)$ could be simultaneously used. Once the poles of the line or of the plane are selected,

10 select a color, then the button "export" should be activated and the output-file has to be

11 selected.

12

\section{4-Projections}

14

The 3D representations of the CMAS tetrahedron allow the user to visualize the relationships and the correlations between compositions of minerals, rocks or both. Although these 3 dimensional representations are very useful, they are sometimes difficult to use, especially if too many data are plotted at the same time. So, projections on a 2 dimension surface are necessary and widely used. These projections involve a projection pole and 3 apices defining a projection plane. These poles and apices can be mineral, compositions, rock compositions or any combination of compositions.

To make projections, the line "Projections" should be selected (No.2, Fig. 2). Then there are two choices in the menu (No.7, Fig. 2): making a projection on a predefined plane (A-CS/2-MS/2; C-M-A; C-A-S; M-A-S or C-M-S) or making a projection on a user-defined plane. In the first case, the line of the chosen plane should be selected (No.7, Fig. 2) whereas, 
1 for the second case, the 3 boxes should be completed with either the number of the line of a

2 sample (from the data.xls type file, Table 1) or with the abbreviation of a mineral (Table 2).

3 The "projection pole" definition should be completed in the same way. An output filename

4 should be written in the box "name of the projection output file here". The projection will be

5 activated by pressing the "export" button. The coordinates of the projected samples are

6 written in the "Command Window" (No.2, Fig. 1). The fourth column indicates the quality of

7 the projection. The bigger the number is, the closer from the projection pole is the projected

8 point, and the poorer the quality of the projection. A negative value indicates that the pole is

9 between the plane and the projected point. Projection results are stored in the folder

"CMAS_1.2Itriangle"

5-Visualization of results

13

The visualization of results should be made with a VRML reader (to read the *.wrl) because the visualization in MATLAB is not so convenient. The files in

C:ICMAS_1.2\Results and C:ICMAS_1.2ltriangle should be opened with this type of reader. Some free VRML readers are available on the web; we propose to use "Flux Player" freely downloadable at http://www.mediamachines.com (also provided with the supplementary material). The mouse commands to move the tetrahedron are: left button: rotation, right button: displacement, rolling button: zoom.

Note that in order to have an image easily modifiable, the names of the apices are not given in the results of the projection. For the projection, the name of the apices must be in a precise order (No.7, Fig. 2): the first apex name will be the left one, the second one will be the right one and the third one will be the top one. 


\section{6-Example}

.

.

4
products is represented by the balanced centroid on a line (for two reagents or products), on a plane (for three reagents or products) or in a polyhedron (for more than three reagents or products). A metamorphic reaction is chemically supported only if in the composition plots in the chemical space and so in the CMAS chemical reduced space, the balanced centroid of the reagents and the one of the products have the same coordinates. In mantle conditions, in the subsolidus domain, two reactions separate the Seiland subfacies from the Ariegite one (both subfacies being in the spinel lherzolites facies; Fig.3). These reactions are $O p x+P l+S p \Leftrightarrow G t+C p x$ and $O p x+P l+S p \Leftrightarrow G t+S a p p h$ (with Opx: orthopyroxene, Pl: plagioclase, Sp: spinel, Gt: garnet, Cpx: clinopyroxene and Sapph: sapphirine) and are located in the P-T space on Figure 3. The reaction involving Cpx is well known from granulites and pyroxenites studies (e.g.: Grégoire et al., 1994) and the one involving the sapphirine has been evidenced by Christy (1989). These reactions are represented in the CMAS tetrahedron by a plane (Opx-Pl-Sp) which is crosscut by a line joining Gt-Cpx and Gt-Sapph, respectively. Cpx and Sapph being situated at the opposite regarding the plane (Opx-Pl-Sp), only one reaction could be effective depending on the position of Gt as regard of the plane. Gt is very close of this plane so precise calculations and graphical representations have to be used to know which reaction is effective. The involvement of Sapph has been reported several times in mantle or in deep crustal domains (Grégoire et al., 1994; Herd et al., 1969; Meyer and Brookins, 1976; Segnit, 1957) and its origin is never very well understood, the use of CMAS 3D allows to resolve such a problem.

4 A pyroxenite xenolith from Morocco (TAK-4) is made of clinopyroxene, garnet, spinel, plagioclase and sapphirine. Electron microprobe data for these minerals (Table 1) have 
1 been plotted in a CMAS tetrahedron using CMAS 3D and are presented on the Figure 4 as

2 well as the Opx-Pl-Sp plane. On a projection from the plagioclase pole (Fig.5), the Opx-Pl-Sp

3 plane (represented as a line) is crosscut by the Gt-Sapph line, showing that these two minerals

4 are the products of a reaction involving plagioclase, spinel and orthopyroxene. The

5 observation that Gt is close to the Opx-Pl-Sp plane implies that the amount of sapphirine

6 formed during the reaction is very small, which is confirmed by microscopic observations on

7 thin sections.

7-Conclusion

11 CMAS 3D provides the possibility to project and to visualize chemical data (weight percent of oxides) within the CMAS system in 3 dimensions and to make 2 dimensions projections very easily. Petrologists and geochemists commonly compile their data with Microsoft

14 Excel $^{\mathrm{TM}}$ so CMAS 3D uses an Excel source file to make representations and projections. The 15 calculations are made by CMAS 3D with MATLAB ${ }^{\circledR}$ and the results can be visualized with 16 free downloadable software. The 3D visualizations are very easy to use and provide a very 17 convenient tool for research as well as for teaching igneous and metamorphic petrology.

\section{Acknowledgments}

21 The manuscript has been largely improved thanks to the constructive and patient reviews by

22 Alexei Fedkin and James Kelly Russell. We are also grateful to Eric Grunsky, Editor-in-Chief 23 for his support.

\section{References}


2 Basaltic Volcanism Study Project, basaltic volcanism on the terrestrial planets, Pergamon, New York, 1981.

4 Carr, M., 1995. IGPET. Software Program. Terra Softa Inc., 155 Emerson RD., Somerset, NJ 08873.

6 Christy, A.G., 1989. The stability of Sapphirine+Clinopyroxene: implications for phase relations in the CaO-

$\mathrm{MgO}-\mathrm{Al}_{2} \mathrm{O}_{3}-\mathrm{SiO}_{2}$ system under deep-crustal and upper mantle conditions. Contributions to Mineralogy and Petrology 102, 422-428.

9

Clarke, D., 1993. NEWPET software program. Departement of Earth Sciences, Memorial University of

11 Newfoundland, St Johns, Newfoundland, Canada.

12

13 Garrido, C.J., Bodinier, J.L., 1999. Diversity of mafic rocks in the Ronda peridotite: Evidence for pervasive 14 melt-rock reaction during heating of subcontinental lithosphere by upwelling asthenosphere. Journal of Petrology 40(5), 729-754.

Grégoire, M., Mattielli, N., Nicollet, C., Cottin, J.Y., Leyrit, H., Weis, D., Shimizu, N., Giret, A., 1994. Oceanic mafic granulite xenoliths from the Kerguelen archipelago. Nature 367, 360-363.

Grossman, L., Fedkin, A.V., 2003. CaO-MgO-Al2O3-SiO2 liquids: Chemical and isotopic effects of Mg and Si evaporation in a closed system of solar composition. Geochim. Cosmochim. Acta 67, 4205-4221.

Grossman, L., Ebel, D.S., Simon, S.B., 2002. Formation of refractory inclusions by evaporation of condensate precursors. Geochim. Cosmochim. Acta 66, 145-161.

Herd, R.K., Windley, B.F., Ghisler, M., 1969. The mode of occurrence and petrogenesis of the sapphirinebearing and associated rocks of West Greenland. Rapp Gronlands Geol. Unders. 24, 44p. of garnet pyroxenite. Geology 31(6), 481-484. 
2 Kogiso, T., Hirschmann, M.M., Frost, D.J., 2003. High-pressure partial melting of garnet pyroxenite: possible mafic lithologies in the source of ocean island basalts. Earth Planet. Science Letters 216, 603-617.

4

Kogiso, T., Hirschmann, M.M., Pertermann, M., 2004. High pressure partial melting of lithologies in the mantle. Journal of Petrology 45(12), 2407-2422.

Kornprobst, J., 1970. Les péridotites et les pyroxenolites du massif ultrabasique des Beni Bouchera : une étude experimentale entre 1100 et 1550C sous 15 à 30kilobars de pression sèche. Contr. Mineral. Petrol. 29, 290-309.

Kornprobst, J., Conquéré, F., 1972. Les pyroxenolites à grenat du massif de lherzolite de Moncaup (haute Garonne-France); caractère communs avec certaines enclaves des basaltes alcalins. Earth Planet. Science Letters $16,1-14$.

14

Leake, B.E., Woolley, A.R., Arps, C.E.S., Birch, W.D., Gilbert, M.C., Grice, J.D., Hawthorne, F.C., Kato, A.,

16 Kisch, H.J., Krivovichev, V.G., Linthout, K., Laird, J., Mandarino, J.A., Maresch, W.V., Nickel, E.H., Rock,

N.M.S., Schumacher, J.C., Smith, D.C., Stephenson, N.C.N., Ungaretti, L., Whittaker, E.J.W., Youzhi, G., 1997.

Nomenclature of amphiboles-report of the subcommittee on amphiboles of the international mineralogical association, commission on new minerals and mineral names. The Canadian Mineralogist 35, 219-246. amphiboles-additions and revisions to the international mineralogical association's 1997 recommendations. The Canadian Mineralogist 41, 1355-1362. 
O'Hara, M.J., 1968. The bearing of phase equilibria studies in synthetic and natural systems on the origin and evolution of basic and ultrabasic rocks. Earth-Science Reviews 4, 69-133.

O’Hara, M.J., 1976. Data reduction and projection schemes for complex compositions. in Progress in experimental petrology, N.E.R.C. Publication Series D, 6, 103-126.

6

Petrelli, M., 2003. Petrograph: a new software for the analysis and presentation of geochemical data.

Richard, L.R., 1997. MinPet. Software program, MinPet Geological Software, 294 Mont-Fleuri, Gatineau, J8R $2 \mathrm{H} 6$.

Schiano, P., Eiler, J.M., Hutcheon, I.D., Stolper, E.M., 2000. Primitive CaO-rich, silica-undersaturated melts in 14 island arcs: Evidence for the involvement of clinopyroxene-rich lithologies in the petrogenesis of arc magmas.

Schiano, P., Clocchiatti, R., Boivin, P., Medard, E., 2004. The nature of melt inclusions inside minerals in an ultramafic cumulate from Adak volcanic center, Aleutian arc: implications for the origin of high-Al basalts.

Chemical Geology 203, 169-179.

Segnit, E.R., 1957. Sapphirine-bearing rocks from MacRobertson Land Antarctica. Mineral Mag. 31, 690-697. 


\section{A MATLAB}

File Edit View Web Window Help

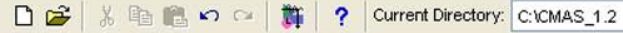

Current Directory

C: $\backslash$ CMAS_1.2

All Files

$\square$ criangle Dinterface $\square$ Resultats

圂兽 cris.m

[ colorscsymols.jpg JPG Fil

CDesktop.ini

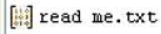

QThumbs.db

INI File

TXT File

DB File

$\checkmark$...

\section{त्रा $x$}

A.

Last Modified

22-juin-2006 03:17

11-mai-2006 05:27

11-mai-2006 05:27

11-juil.-200 06:34

11-oct. -2007 03:30

22-juin-2006 03:17

10-janv. -200 06:43

31-mars-2008 06:10

Descript
Command Window

Using Toolbox Path Cache. Type "help toolbox_path_cache" for more info.

To get started, select "MATLAB Help" from the Help menu.

$\gg$ cras

(2)

\section{A Start}




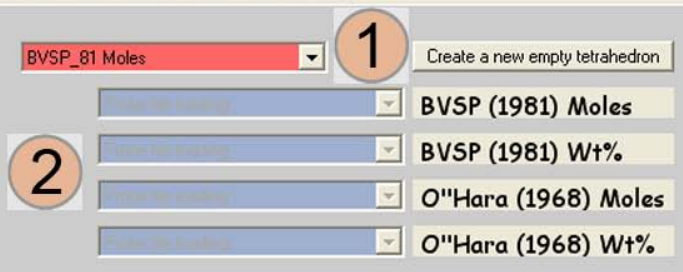

Aegyrine aeg

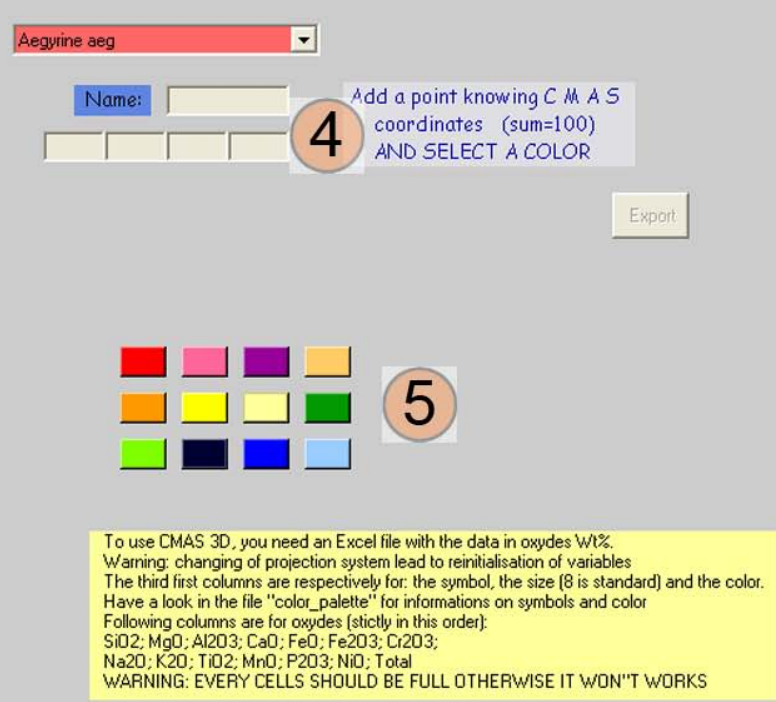

enter here tetrahedron name

\section{CMAS 3D tetraedron drawing

drawing

no file

3

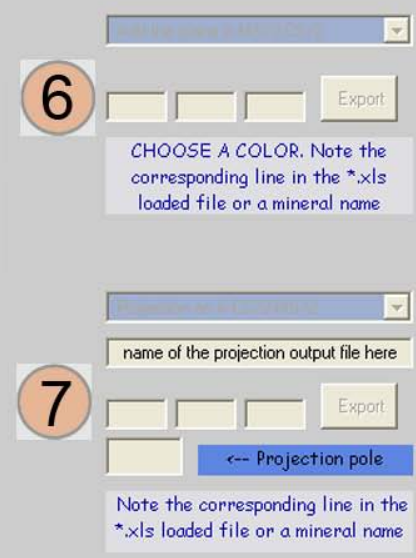

Note the corresponding line in the

*xls loaded file or a mineral name

CHOOSE A COLOR. Note the corresponding line in the ${ }^{*}, x \mid s$ loaded file or a mineral name

ame of the projection output file here 


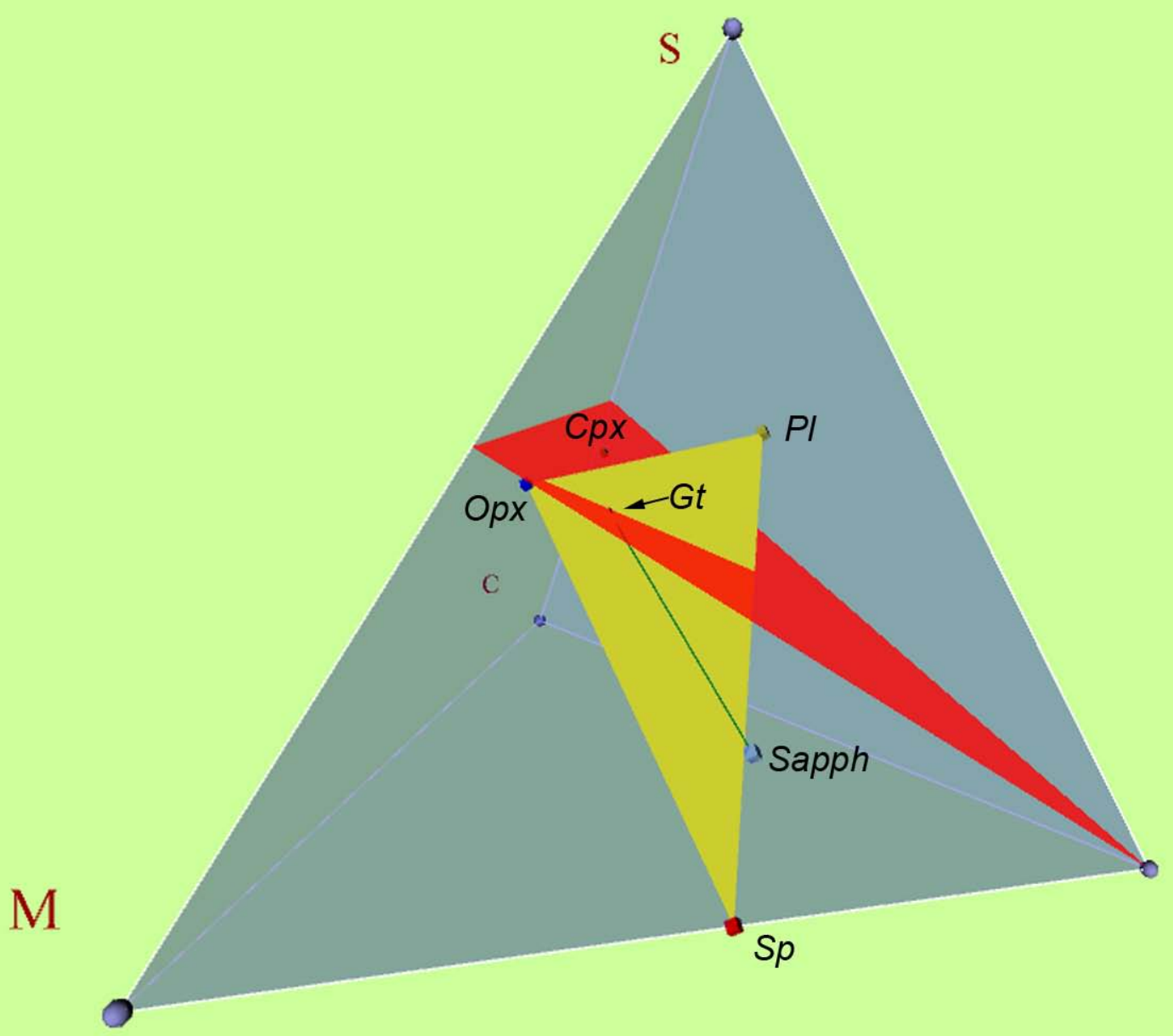




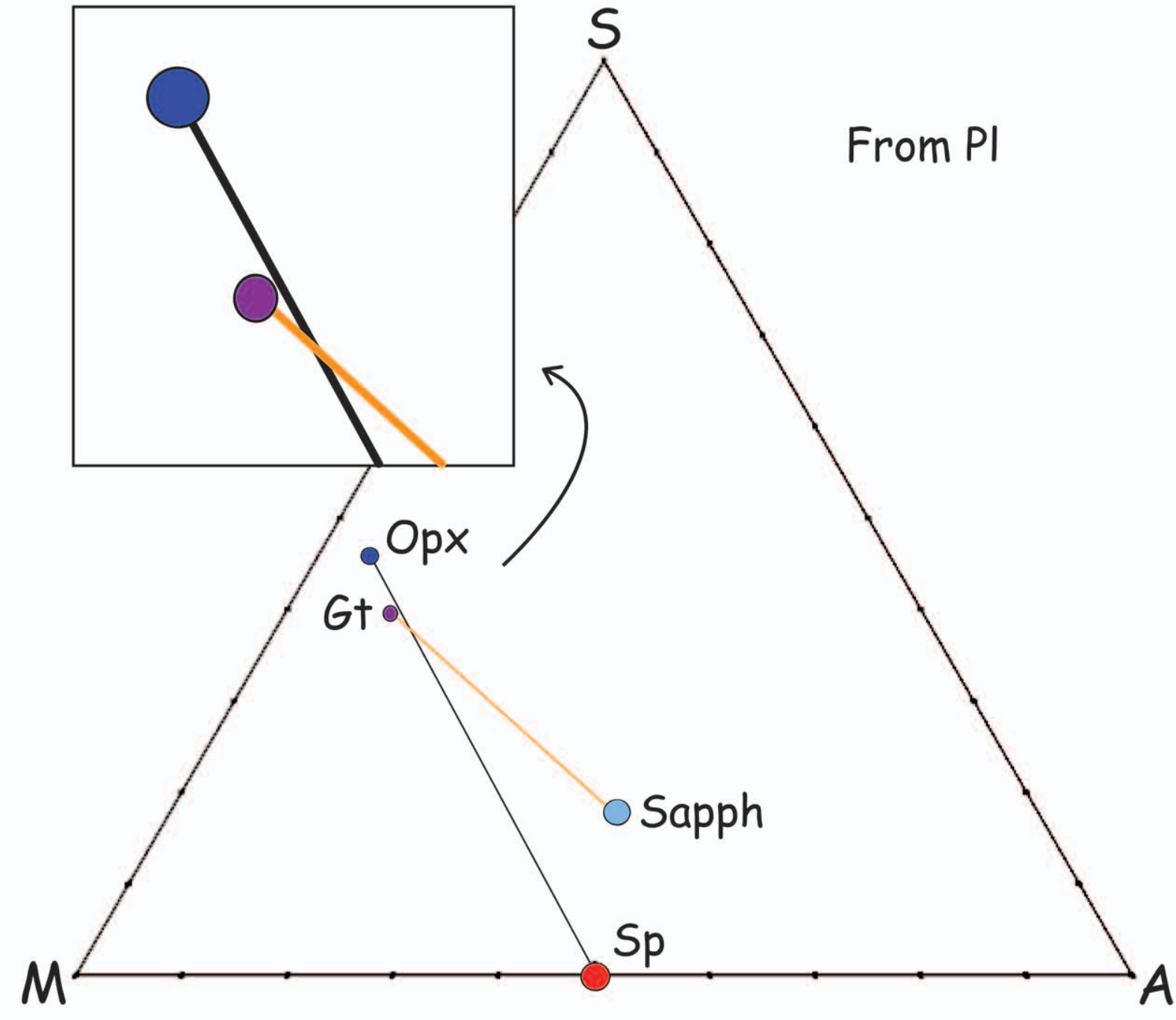




\begin{tabular}{|c|c|c|c|c|c|c|c|c|c|c|c|c|c|c|c|c|c|}
\hline Samples & Symbol & Size & Color & SiO2 & MgO & $\mathrm{Al} 2 \mathrm{O} 3$ & $\mathrm{CaO}$ & $\mathrm{FeO}$ & $\mathrm{Fe} 2 \mathrm{O} 3$ & Cr2O3 & $\mathrm{Na2O}$ & $\mathrm{K} 2 \mathrm{O}$ & TiO2 & MnO & P2O5 & $\mathrm{NiO}$ & Total \\
\hline Cpx & 2 & 7 & 8 & 50.60 & 13.83 & 10.31 & 21.49 & 2.26 & 0.00 & 0.18 & 1.50 & 0.01 & 0.14 & 0.03 & 0.00 & 0.00 & 100.33 \\
\hline Gt & 2 & 6 & 3 & 42.87 & 20.93 & 24.12 & 6.26 & 6.39 & 0.00 & 0.13 & 0.03 & 0.01 & 0.03 & 0.16 & 0.00 & 0.00 & 100.92 \\
\hline $\mathrm{Sp}$ & 2 & 12 & 1 & 0.04 & 23.32 & 66.18 & 0.02 & 7.45 & 0.00 & 1.55 & 0.01 & 0.00 & 0.01 & 0.01 & 0.00 & 0.00 & 98.60 \\
\hline $\mathrm{Pl}$ & 2 & 12 & 6 & 49.29 & 0.30 & 31.68 & 13.87 & 0.28 & 0.00 & 0.02 & 2.84 & 0.29 & 0.00 & 0.00 & 0.00 & 0.00 & 98.57 \\
\hline Opx & 2 & 8 & 11 & 50.91 & 30.34 & 11.19 & 1.46 & 6.44 & 0.00 & 0.13 & 0.07 & 0.02 & 0.06 & 0.14 & 0.00 & 0.00 & 100.81 \\
\hline Sapph & 2 & 12 & 12 & 15.20 & 20.56 & 59.58 & 0.09 & 3.11 & 0.00 & 0.82 & 0.03 & 0.01 & 0.02 & 0.02 & 0.00 & 0.00 & 99.43 \\
\hline
\end{tabular}




\begin{tabular}{|c|c|}
\hline Mineral/Pole & To write \\
\hline $\mathrm{C}$ & C, c \\
\hline M & M, m \\
\hline A & A, a, Crn, crn \\
\hline S & S, s, Q, q, Qtz, qtz \\
\hline aegerine & Aegerine, Aeg, aeg, aegerine \\
\hline albite & Albite, albite, Ab, ab, $\mathrm{Pl}, \mathrm{pl}$ \\
\hline almandine & Almandine, almandine, alm, Alm \\
\hline Alumina silicate & $\begin{array}{c}\text { Andalusite, andalusite, And, and, Kyanite, } \\
\text { kyanite, Ky, ky, Sillimanite, sillimanite, } \\
\text { Sil, sil }\end{array}$ \\
\hline anorthite & Anorthite, anorthite, An, an \\
\hline Ca-Tschermack & CaTs, cats \\
\hline chromite & Chromite, chromite, chr, Chr \\
\hline cordierite & Cordierite, cordierite, Crd, crd \\
\hline diopside & Diopside, diopside, Di, di, Cpx, cpx \\
\hline enstatite & $\begin{array}{c}\text { Enstatite, enstatite, Opx, opx, En, en, MS, } \\
\mathrm{ms}, \mathrm{MS} / 2, \mathrm{~ms} / 2\end{array}$ \\
\hline olivine & $\begin{array}{l}\text { Olivine, olivine, Ol, ol, Forsterite, } \\
\text { forsterite, Fo, fo, Fayalite, fayalite, Fa, fa }\end{array}$ \\
\hline ferrosilite & Ferrosilite, ferrosilite, Fs, fs \\
\hline grossular & Grossular, grossular, Grs, grs \\
\hline heddenbergite & Heddenbergite, heddenbergite, $\mathrm{Hd}$, hd \\
\hline hematite & Hematite, hematite, Hem, hem \\
\hline ilmenite & Ilmenite, ilmenite, Ilm, ilm \\
\hline jadeite & Jadeite, jadeite, Jd, jd \\
\hline magnetite & Magnetite, magnetite, Mag, mag \\
\hline Mg-Tschermack & MgTs, mgts \\
\hline orthoclase & Orthoclase, orthoclase, Or, or \\
\hline pleonaste & Pleonaste, pleonaste, Ple, ple \\
\hline pyrope & Pyrope, pyrope, Prp, prp \\
\hline sapphirine & Sapphirine, sapphirine, Spr, spr \\
\hline spinel & Spinel, spinel, Spl, spl \\
\hline wollastonite & $\begin{array}{l}\text { Wollastonite, wollastonite, Wo, wo, CS, } \\
\text { cs, CS/2, cs/2 }\end{array}$ \\
\hline tremolite-actinote & $\begin{array}{c}\text { Actinote, Tremolite, actinote, tremolite, } \\
\text { act, Act, tr, Tr }\end{array}$ \\
\hline $\begin{array}{l}\text { anthophyllite- } \\
\text { cummingtonite }\end{array}$ & $\begin{array}{c}\text { Anthophyllite, Cummingtonite, Grunerite, } \\
\text { anthophyllite, cummingtonite, grunerite, } \\
\text { ath, Ath, cum, Cum, gru, Gru }\end{array}$ \\
\hline gedrite & Gedrite, gedrite, Ged, ged \\
\hline edenite & Edenite, edenite, Ed, ed \\
\hline pargasite-hastingsite & $\begin{array}{l}\text { Pargasite, Hastingsite, pargasite, } \\
\text { hastingsite, prg, Prg, Hs, hs }\end{array}$ \\
\hline tschemakite & Tschemakite, tschermakite, Ts, ts \\
\hline hornblende & Hornblende, hornblende, $\mathrm{Hbl}$, hbl \\
\hline chlorites & $\begin{array}{l}\text { Chlorite, chlorite, Clinochlore, clinochlore, } \\
\text { Chamosite, chamosite, Chl, chl }\end{array}$ \\
\hline
\end{tabular}

